\title{
EFFECTS OF SLIPPERY JACK (SUILLUS LUTEUS) ON THE HEAVY METAL ACCUMULATION AND SOIL PROPERTIES OF MASSON'S PINE (PINUS MASSONIANA LAMB) IN A MINING AREA OF CHINA
}

\author{
SUN, Y. J. ${ }^{1 \#}-$ YU, P. Y. ${ }^{\#}-$ CHEN, J. Z. ${ }^{2}-$ LI, S. M. ${ }^{1}-$ JIANG, L. J. ${ }^{*}$ \\ ${ }^{1}$ College of Life Science and Technology, Central South University of Forestry and Technology, \\ 498 South Shaoshan Road, Changsha, Hunan 410004, China \\ ${ }^{2}$ Hunan Academy of Forestry, 658 South Shaoshan Road, Changsha, Hunan 410004, China \\ ${ }^{\#}$ These authors contributed equally to this work \\ *Corresponding author \\ e-mail: znljiang2542@163.com \\ (Received $17^{\text {th }}$ Jan 2020; accepted $24^{\text {th }}$ Mar 2020)
}

\begin{abstract}
Plant-microbial bioremediation is an efficient way to treat heavy metal contaminated soils. In order to reveal the potential mechanisms of ectomycorrhizal fungi mutualistic symbiosis for remediating heavy metal contaminated soils, the masson's pine associated with ectomycorrhizal fungi (Suillus luteus) and control treatments (plant roots without ectomycorrhizal fungi) were planted in a $\mathrm{Pb}$ and $\mathrm{Zn}$ contaminated mining area in the south of China. The results showed that the growth of masson's pine seedlings were significantly higher in the treated group than in the control group. The bioconcentration factor (BCF) of heavy metals inoculated with Suillus luteus was 1 to 5 times higher than that of those in control group. However, the translocation factor (TF) of heavy metals in treated group decreased by 50\% compare to the control group. Both selenium and potassium content significantly improved the functions of oxidation and stress resistance in symbiotic systems. The activity of the urease and alkaline phosphatase in the soil was significantly improved in treated group. The soil available $\mathrm{N}, \mathrm{P}$ and $\mathrm{K}$ contents, and the ratio of $\mathrm{C} / \mathrm{N}$ was increased compared to the control. In conclusion, the ectomycorrhizal fungi could improve soil physicochemical properties, and enhance nutrient absorption by the plants, which would be favorable to the growth of plants in the soil contaminated with heavy metals.
\end{abstract}

Keywords: bioremediation, heavy metal toxicity, enzyme activities, mycorrhiza, symbiosis systems

\section{Introduction}

Soils may be contaminated by the accumulation of heavy metals through emissions from the rapidly expanding mine tailings. The water and soil erosion caused by deforestation in abandoned mining area had polluted the surrounding soil with heavy metals severely, which resulted in impacts on the growth and development of wild life, plants and human activities in central south of Hunan, China (Ayangbenro and Babalola, 2017; Huang et al., 2012). To remediate hazardous pollutants of heavy metal ions have attracted more attention (Li et al., 2019).

There were many methods reported to restore or remediate heavy metal contaminated soil, for example, physcio-chemically, to fix available heavy metals in soils by means of welding, stabilizing, excavating and electrodynamics, so that the effective concentration (EC) of heavy metals were reduced to harmless level (Sheoran et al., 2011; Wuana and Okieimen, 2011). However, these methods would inevitably damage the natural structure of soil by adding curing agent. Also the improper storage 
of the contaminated soil after curing might result in secondary pollution. In contrast, the bioremediation method constructed by plant roots and ECM fungi was environmentally friendly. The symbiotic system could immobilize, accumulate and transfer excessive heavy metals through the absorption of water and nutrients in soil (Ma et al., 2019; Guo et al., 2020).

Many reports, in recent years, showed that the heavy metal contaminated soils, such as abandoned mining areas and tailings reservoir areas, did harm to the growth and development of plants considering the physiologically and the survival of herbaceous plants (Zhang and Ji, 2019; Zhang et al., 2018). However, some woody plants such as Fagaceae (Tam, 1995; Sozoniuk et al., 2019) or Pinaceae (Wang et al., 2019) coexisted with ectomycorrhizal (ECM) fungi, which could supply the host plants with water and nutrient (Colpaert, 2008), and promote these plants to survive in the toxicity of heavy metals in mining areas (Lalancette et al., 2019). According to Jentschke and Godbold (2000), the roots of almost all forest tree seedlings rely on mycorrhizal fungi, which could shift the absorption and translocation of heavy metal stress in roots system and ameliorate the toxicity of heavy metals to the aboveground of host plants (Jentschke and Godbold, 2000). Compared with the plants inoculated without ECM fungi, Pinus sylvestris inoculated with six strains of ECM fungi immobilized larger numbers of zinc in the roots, and limiting the transportation of zinc to the host plants of Pinus sylvestris (Colpaert, 2008). As well as Sousa et al. (2012) mentioned that ECM fungi (Suillus bovinus) would improve shoot development of Pinus pinaster seedlings up to $30 \%$ exposure to the soil contaminated by $\mathrm{Cd}$, and the accumulation of $\mathrm{Cd}$ in the aboveground parts of the seedlings inoculated with $S$. bovinus seedlings also increased (Sousa et al., 2012). Other studies also showed that masson's pine inoculated with ECM fungi was more tolerant to higher concentrations of heavy metals than the non-ECM fungi inoculation, and ECM fungi had a great effect on the absorption and fixation of heavy metals (Huang et al., 2012).

Masson's pine, a pioneer tree species with large biomass, is regarding as an important timber and industrial material tree species that has ectomycorrhizal in southern China (Sun et al., 2010). Masson's pine exhibits many advantages, such as fast growth, high yield, strong adaptability to drought-stressed soils, and high potential for the phytoremediation of soils that contaminated by heavy metals (Wang et al., 2019; Zhang et al., 2017). Therefore, masson's pine was considered to be an appropriate reforestation tree species in heavy metal contaminated soils in abandoned mining tails area. Suillus luteus could form symbiotic systems with masson's pine (Zhang et al., 2017), Larix principis-rupprechtii (Huai et al., 2003), Picea abies (Krznaric et al., 2009a), Pinus sylvestris (Yin et al., 2014) and so on, and could increase the absorption of nutrients and water, and then promote the growth of symbiotic plants (Luo et al., 2014). However, so far, the effect of ECM fungi on the improvement of host plant remediation potential and adaption under excessive stress of heavy metals in soil are not very clear.

In this study, the effects of masson's pine inoculated with or without ECM fungi on soil properties were investigated. The objectives of the study were 1) the characteristics of absorption, accumulation and transportation of heavy metals and nutrients of masson's pine inoculated with Suillus luteus compared to the control (without ECM fungi) in the mining areas contaminated soil by lead-zinc; 2) to address the mechanisms of mycorrhiza and plant mutualistic symbiosis system on the soil physicochemical properties and the activities of enzymes in masson's pine rhizosphere. 


$$
-3743-
$$

\section{Materials and methods}

\section{Experimental site}

The experimental site is located in an abandoned lead-zinc mining tails of mountain Manao in the southeast of Chenzhou city, Hunan Province, China (Fig. 1). Miscanthus sp, Equisetum ramosissimum, Elsholtzia cypriani are the dominate plants species growing in the abandoned mining tails area that are seriously polluted by lead $(\mathrm{Pb})$ and zinc $(\mathrm{Zn})$ heavy metals. The area is at the northern foot of middle section of the mountain Nanling $\left(13^{\circ} 08^{\prime} 00^{\prime \prime} \sim 113^{\circ} 08^{\prime} 30^{\prime \prime} \mathrm{E}, 25^{\circ} 35^{\prime} 00^{\prime \prime} \sim 25^{\circ} 44^{\prime} 00^{\prime \prime} \mathrm{N}\right)$. It is a continental subtropical monsoon humid climate, with distinct four seasons, abundant sunshine and the rainfall, but unevenly distributed. As "hometown of non-ferrous metals", the mountainous and hilly are rich in mineral resources, have less arable land and water. Due to extensive mining, there is a series of problems such as soil erosion, eco-environment deterioration, and heavy metals pollution. Therefore, the native plant species, such as Koelreuteria paniculata, Sapium sebiferum, Pinus massoniana Lamb, and Quercus, growing in the polluted site are endangered. It is urgently needed to protect and reforest plants and tree species in the whole area, particularly the mining tailings.

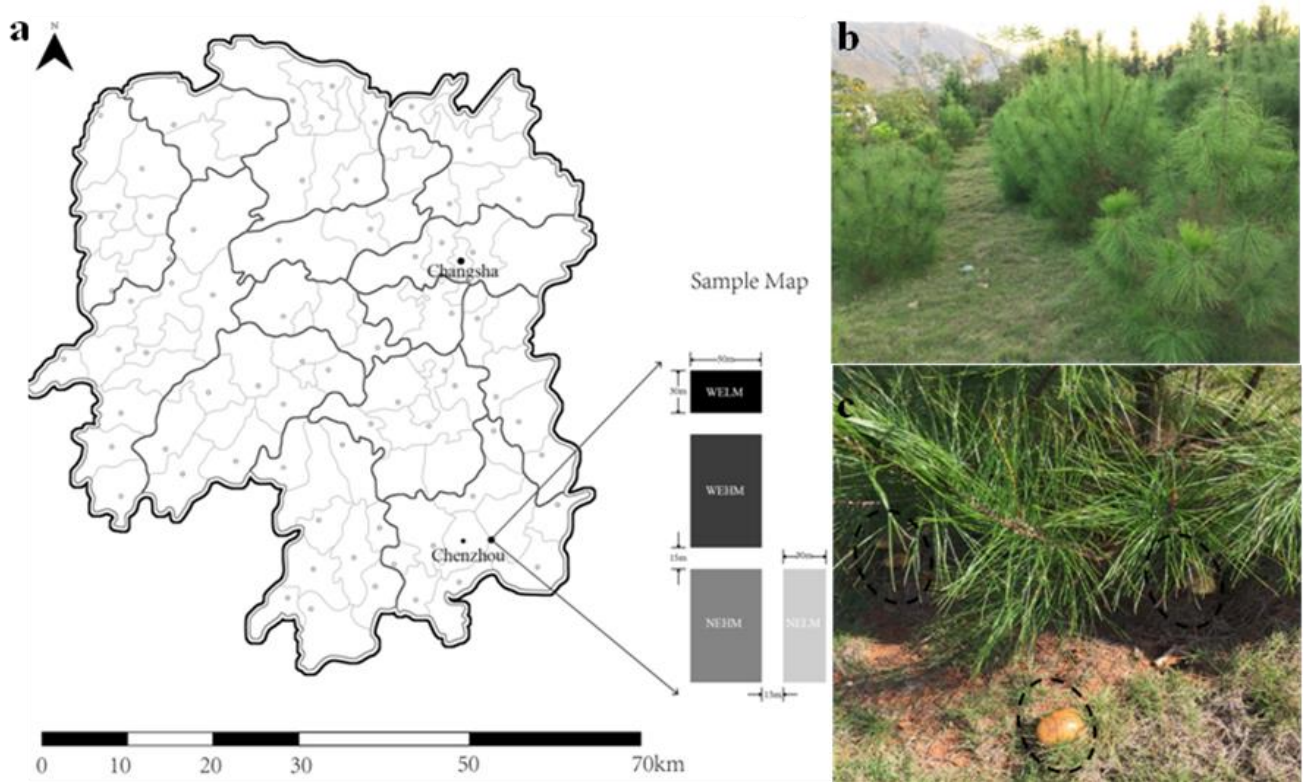

Figure 1. Location of the study area and plot setting. (Note: a refers to the experimental site, $b$ refers to the growth condition of masson's pine, and c refers to the sampling site inoculated with Suillus luteus; the capital letter WELM refers to low heavy metals contaminated soil inoculated with ECM fungi, WEHM refers to high heavy metals contaminated soil inoculated with ECM fungi, NELM refers to low heavy metals contaminated soil inoculated without ECM fungi, NEHM refers to high heavy metals contaminated soil inoculated without ECM fungi)

\section{Experiments design}

The plants used in this experiment were two-year-old masson's pine seedlings inoculated with and without ECM fungi, which were provided by Hunan academy of forestry. The seedlings inoculated with EMC were cultivated by the way of Yu et al. (2020). At the end of 2016, the masson's pine seedlings inoculated with ECM fungi (WE) and without inoculation (NE) were planted in two polluted areas with two different levels of $\mathrm{Pb}$ and $\mathrm{Zn}$ 
contamination degree in soil, the low heavy metal contaminated soil (LM) and the high heavy metal contaminated soil (HM). The polluted soils combine with the treatment inoculated with ECM fungi (WE) named as WELM, WEHM, and the polluted soils inoculated without ECM fungi (NE) named as NELM, NEHM. There was no polluted soil $(\mathrm{NM})$ based on the $\mathrm{Pb}$ and $\mathrm{Zn}$ contaminated degree below the Hunan background and national standard II (see Table 1) with NE treatment only (names as CK) in the experiment. There were three replications in both LM and HM soils. Before the experiment to set up, we have measured the no polluted soil samples with WE and NE treatments, and we found that no significant difference between the treatment and control. So that there were three WELM, three WEHM, three NELM, three NEHM, and three NENM of the treatments, the total of 15 sampling plots in the experimental study, and each plot included 3 trees. The heavy metal contents in different plots were showed in Table 1.

Table 1. Heavy metals content of soil in different planting areas of masson's pine $(\mathrm{mg} / \mathrm{kg})$

\begin{tabular}{c|c|c|c|c|c}
\hline Soil type & Pb & Zn & Cu & Cd & Mn \\
\hline CK & 20.93 & 87.47 & 23.69 & 0.13 & 686.10 \\
LM & 602.35 & 400.93 & 44.93 & 0.32 & 1222.93 \\
HM & 2555.20 & 496.75 & 57.52 & 0.473 & 2010.83 \\
Hunan background & 29.7 & 94.4 & 27.3 & 0.17 & - \\
National standard & $\leq 250$ & $\leq 200$ & $\leq 150$ & $\leq 0.30$ & - \\
II & & & & & - \\
\hline
\end{tabular}

CK refers to no heavy metal polluted soil without ECM fungi; LM refers to the low heavy metal contaminated soil; HM refers to the high heavy metal contaminated soil

\section{Plant growth determination and sampling}

From June 2017 to May 2019, the plant heights, ground diameters, crown width and annual branch length of masson's pine were measured. Meanwhile, three root, stem and leaf samplings of each masson's pine inoculated with ECM fungi (including WELM and WEHM), without ECM fungi (including NELM and NEHM) and CK treatment were collected, and the root, stem and leaf samplings from each plot was mixed into one sample, respectively, we totally got 15 root samplings, 15 stem samplings, and 15 leaf samplings. Then, heavy metals and nutrient element contents were determined. Notably, root samplings of each plant were carefully excavated by soil core sampler $(\varphi 108 \mathrm{~mm} \times$ $\varphi 100 \mathrm{~mm} \times 130 \mathrm{~mm}$ ), the soil attached to the root surface was took as rhizospheric soils, and the depth of sampling was 10 to $20 \mathrm{~cm}$.

\section{Soil sampling}

The soil samples were taken in each plot before the seedlings of masson's pine planting and the soil physicochemical properties were measured (Table 1). Two years after planting the seedlings of masson's pine, root samplings of each plant were carefully excavated and the soil attached to the root surface of masson's pine was collected and packed in a sealed plastic bag. The gravel, plant litter and other visible impurities were removed. The sampled soil was divided into two categories: one was stored in refrigerator at $-20{ }^{\circ} \mathrm{C}$ for the determination of soil enzyme activities of the soil, and the other one was air-dried at room temperature for the determination of soil physicochemical properties. 


\section{Determination of soil physicochemical properties}

The soil was dried in oven at $70{ }^{\circ} \mathrm{C}$ for $48 \mathrm{~h}$ for measuring water content. Took $1 \mathrm{~g}$ soil dissolved in $5 \mathrm{ml}$ distilled water and shaken for $30 \mathrm{~min}$, and was measured by glass electrode (Sartorius PB-10). Soil total carbon (TC) and total nitrogen (TN) were determined by element analyzer (VarioEL III, Germany). The available phosphorus (AP) in soil was extracted by sodium bicarbonate and determined with molybdenumblue method, the available potassium (AK) was determined by flame spectrophotometry, and available nitrogen (AN) was measured by means of alkaline hydrolysis diffusion method (Bao, 2000).

\section{Determination of total heavy metal concentrations in plants and soils}

The dried plants were divided into two parts, belowground part and aboveground (stem and leaf) parts. After smashed, both of $0.3 \mathrm{~g}$ plant and soil samples were weighed accurately, then digested by microwave acid digestion (EPA 3051; USEPA, 2004). The heavy metal concentrations were determined by Inductively Coupled Plasma Emission Spectrometer (ICP-MS, X-7, Thermo Electron, Waltham, MA, USA) (Zhao et al., 2013). All samples were repeated for three times and then took the average value was taken.

\section{Determination of soil enzyme activities}

The activity of catalase was defined as decomposing one milligram of soil hydrogen peroxide every $30 \mathrm{~min}$, and determined by ultraviolet spectrophotometry. A unit $(\mu)$ of urease active was defined as producing the mass of $\mathrm{NH}_{3}-\mathrm{N}$ by hydrolyzing $1 \mathrm{~g}$ soil for $1 \mathrm{~min}$, and determined by sodium phenol-sodium hypochlorite colorimetry. The activity of alkaline phosphatase was defined as producing the mass of phenol with $1 \mathrm{~g}$ of soil after $24 \mathrm{~h}$, and determined by disodium phosphate colorimetric method. The activity of sucrose enzyme was defined as producing the mass of glucose with $1 \mathrm{~g}$ of soil after $24 \mathrm{~h}$, and determined by 3, 5 dinitrosalicylate colorimetric method (Guan et al., 1986).

\section{Statistical analysis}

The means of the growth vigor of masson's pine, the absorption of heavy metals and nutrient elements, and soil physicochemical properties had been compared within Microsoft s Excel (Office' 2000), One-way analysis of variance (ANOVA) and The correlation between the soil physicochemical properties and plant nutrients was performed to determine the effects of above factors by using SPSS (version 19.0; SPSS, Chicago, IL, USA)

\section{Results}

\section{Effects of ECM fungi on the growth of masson's pine}

The mean height, ground diameter, annual branch length and crown width of masson's pine seedlings inoculated with/without EMC and the control in different contaminated soils are shown in Figure 2. The mean height and annual branch growth of seedlings with NE treatment were decreased compared to the no polluted soil treatment $(\mathrm{CK})$, especially, there was a significantly difference in plant height $(\mathrm{P}<0.05)$ (Fig. 2a). Seedlings of WELM treatment have improved the mean plant height, annual branch length, ground base diameter and crown width than in others 
( $\mathrm{p}<0.05)$. The mean ground diameter of seedlings in WELM and WEHM plots were increased by $53.12 \%$ and $43.38 \%$, respectively, compared to the NELM and NEHM plots (Fig. 2b).
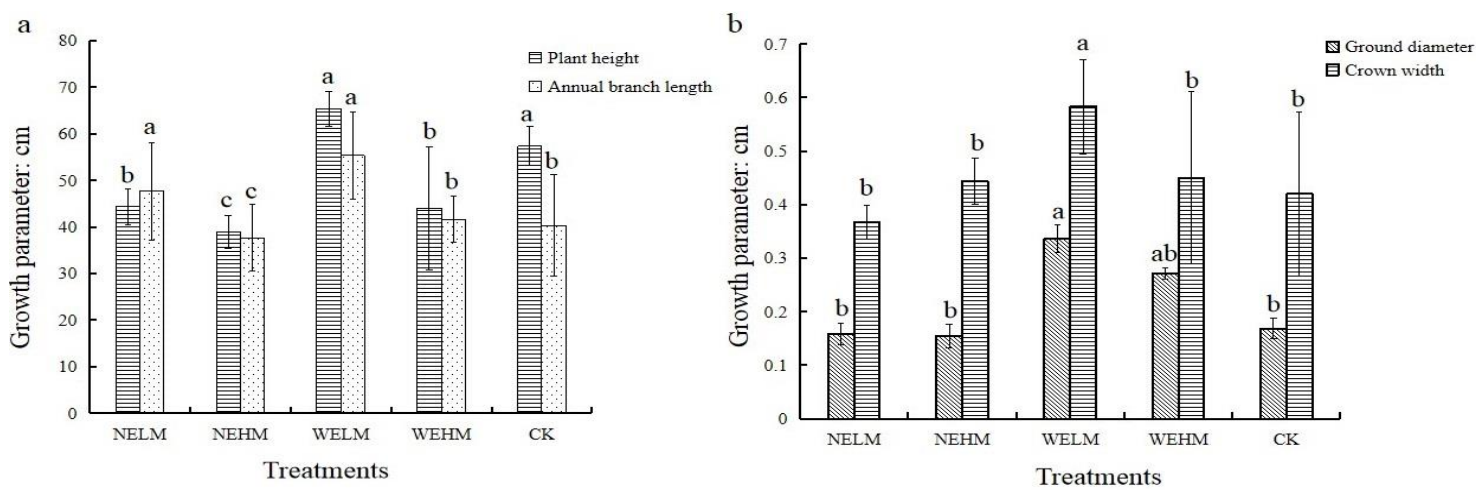

Figure 2. Effects of ectomycorrhizal fungi on the growth of masson's pine. (Note: a refers to the plant height and annual branch length, and $b$ refers to the plant ground base diameter and crown width; the capital letter CK refers to no heavy metal polluted soil without ECM fungi, WELM refers to low heavy metals contaminated soil inoculated with ECM fungi, WEHM refers to high heavy metals contaminated soil inoculated with ECM fungi, NELM refers to low heavy metals contaminated soil inoculated without ECM fungi, NEHM refers to high heavy metals contaminated soil inoculated without ECM fungi; means followed with same letters are not significantly different by Tukey's test multiple comparison at $p<0.05$, mean \pm standard error of three measurements)

\section{Effect of ECM fungi on accumulation and transportation of heavy metals in masson's pine}

The distribution of heavy metal concentrations of masson's pine in different treatments were analyzed (Table 2). The results showed that accumulation of heavy metals of $\mathrm{Pb}, \mathrm{Zn}, \mathrm{Cd}, \mathrm{Cu}$ and $\mathrm{Mn}$ in WE treatment was higher than that of $\mathrm{NE}$ in the plant roots $(\mathrm{p}<0.05)$. The translocation factor $(\mathrm{TF})$ of $\mathrm{Pb}$ was 0.93 , and the bioconcentration factor (BCF) of the root was 0.09 in NEHM plot, which was nearly reach to that of $\mathrm{CK}(\mathrm{TF}=1.26, \mathrm{BCF}=0.55)$. However, the $\mathrm{TF}$ and $\mathrm{BCF}$ of $\mathrm{Pb}$ in WEHM plots were 0.51 and 0.44 , respectively; the TF was about $45 \%$ while the BCF was almost five times of that in NE treatment. The accumulation of $\mathrm{Zn}, \mathrm{Cd}, \mathrm{Cu}$ and $\mathrm{Mn}$ in the roots of WE treatment was increased by 1 to 2 times, while TF was significantly decreased compared to the NE soil.

\section{Effects of ECM fungi on the absorption and distribution of nutrient elements in masson's pine}

The results showed that the TF of selenium in WELM and WEHM treatments were 2.33 and 1.57 times higher than that of NELM and NEHM treatments, respectively (Table 3). The Iron (Fe) in the root system was significantly increased in WEHM treatment, while decreased in aboveground part, especially, in the plant leaves ( $\mathrm{p}<0.05)$. In soil with the same degree of pollution, the average content of $\mathrm{N}$ and $\mathrm{P}$ of the plants in the WE treatment plant were higher than that of NE treatment, but the content ratio of the belowground part to the underground part was lower in WE treatment than that in NE treatment $(\mathrm{p}<0.05)$, except for the $\mathrm{N}$ content of NELM and 
WELM. The content of $\mathrm{K}$ in the plant is lower in WE treatment than that in NE treatment, while the TF of $\mathrm{K}$ is higher in WE treatment than that in NE treatment.

Table 2. The effects of accumulation and transport of heavy metals in masson's pine on different treatments

\begin{tabular}{|c|c|c|c|c|c|c|c|}
\hline Element & Treatment & Soil (mg/kg) & Roots (mg/kg) & Stem $(\mathbf{m g} / \mathbf{k g})$ & Leaf (mg/kg) & \begin{tabular}{|c|} 
Upper \\
part/ground part \\
(TF)
\end{tabular} & $\begin{array}{c}\text { Roots/soil } \\
\text { (BCF) }\end{array}$ \\
\hline \multirow{5}{*}{$\mathrm{Pb}$} & $\mathrm{CK}$ & $20.93 \pm 0.17 \mathrm{c}$ & $11.60 \pm 0.58 \mathrm{~d}$ & $16.53 \pm 2.43 \mathrm{~d}$ & $12.81 \pm 1.84 \mathrm{~d}$ & $1.26 \pm 0.12 \mathrm{a}$ & $0.55 \pm 0.02 \mathrm{a}$ \\
\hline & NELM & $602.35 \pm 15.26 \mathrm{~b}$ & $87.21 \pm 3.11 b c$ & $92.93 \pm 4.24 \mathrm{~b}$ & $60.40 \pm 3.82 \mathrm{~b}$ & $0.88 \pm 0.13 b$ & $0.12 \pm 0.02 b c$ \\
\hline & NEHM & $2555.2 \pm 50.22 \mathrm{a}$ & $229.56 \pm 20.14 \mathrm{a}$ & $73.00 \pm 3.61 b c$ & $21.33 \pm 1.53 \mathrm{c}$ & $0.93 \pm 0.15 b$ & $0.09 \pm 0.01 \mathrm{c}$ \\
\hline & WELM & $602.35 \pm 15.26 \mathrm{~b}$ & $121.60 \pm 10.40 \mathrm{~b}$ & $57.07 \pm 7.69 \mathrm{c}$ & $64.67 \pm 2.01 \mathrm{~b}$ & $0.55 \pm 0.08 \mathrm{c}$ & $0.19 \pm 0.08 \mathrm{~b}$ \\
\hline & WEHM & $2555.2 \pm 50.22 \mathrm{a}$ & $279.23 \pm 18.12 \mathrm{a}$ & $149.43 \pm 8.74 \mathrm{a}$ & $132.88 \pm 3.03 \mathrm{a}$ & $0.51 \pm 0.12 \mathrm{c}$ & $0.44 \pm 0.10 \mathrm{a}$ \\
\hline \multirow{5}{*}{$\mathrm{Zn}$} & CK & $87.47 \pm 2.15 c$ & $41.77 \pm 7.48 \mathrm{~d}$ & $45.07 \pm 3.02 \mathrm{~d}$ & $57.83 \pm 0.51 \mathrm{ab}$ & $1.23 \pm 0.12 \mathrm{a}$ & $0.48 \pm 0.08 \mathrm{~b}$ \\
\hline & NELM & $400.93 \pm 9.51 b$ & $40.67 \pm 5.83 \mathrm{~d}$ & $53.47 \pm 3.78 \mathrm{c}$ & $44.13 \pm 1.51 \mathrm{~b}$ & $1.2 \pm 0.59 \mathrm{ab}$ & $0.10 \pm 0.08 \mathrm{c}$ \\
\hline & NEHM & $496.75 \pm 4.37 \mathrm{a}$ & $67.73 \pm 2.05 \mathrm{c}$ & $90.60 \pm 2.76 \mathrm{~b}$ & $43.10 \pm 2.00 \mathrm{~b}$ & $0.99 \pm 0.26 \mathrm{~b}$ & $0.14 \pm 0.01 b c$ \\
\hline & WELM & $400.93 \pm 9.51 \mathrm{~b}$ & $145.87 \pm 3.26 \mathrm{ab}$ & $66.53 \pm 2.05 \mathrm{~cd}$ & $73.60 \pm 5.25 \mathrm{a}$ & $0.48 \pm 0.01 \mathrm{c}$ & $0.36 \pm 0.12 \mathrm{a}$ \\
\hline & WEHM & $496.75 \pm 4.37 \mathrm{a}$ & $181.77 \pm 16.06 \mathrm{a}$ & $119.20 \pm 3.54 \mathrm{a}$ & $69.20 \pm 4.61 \mathrm{a}$ & $0.52 \pm 0.15 \mathrm{c}$ & $0.37 \pm 0.11 \mathrm{a}$ \\
\hline \multirow{5}{*}{$\mathrm{Cd}$} & $\mathrm{CK}$ & $0.13 \pm 0.01 \mathrm{c}$ & $0.28 \pm 0.07 \mathrm{~d}$ & $0.19 \pm 0.06 \mathrm{c}$ & $0.21 \pm 0.11 \mathrm{~b}$ & $0.71 \pm 0.08 \mathrm{bc}$ & $2.15 \pm 0.13 \mathrm{ab}$ \\
\hline & NELM & $0.32 \pm 0.13 b$ & $0.38 \pm 0.05 \mathrm{c}$ & $0.44 \pm 0.03 \mathrm{~b}$ & $0.28 \pm 0.01 \mathrm{a}$ & $0.95 \pm 0.12 \mathrm{a}$ & $1.18 \pm 0.22 \mathrm{c}$ \\
\hline & NEHM & $0.47 \pm 0.11 \mathrm{a}$ & $0.45 \pm 0.01 b c$ & $0.50 \pm 0.05 \mathrm{a}$ & $0.28 \pm 0.03 \mathrm{a}$ & $0.87 \pm 0.13 b$ & $0.96 \pm 0.16 \mathrm{c}$ \\
\hline & WELM & $0.32 \pm 0.13 b$ & $0.82 \pm 0.02 \mathrm{a}$ & $0.49 \pm 0.16 \mathrm{a}$ & $0.31 \pm 0.09 \mathrm{a}$ & $0.49 \pm 0.15 \mathrm{c}$ & $2.56 \pm 0.82 \mathrm{a}$ \\
\hline & WEHM & $0.47 \pm 0.11 \mathrm{a}$ & $0.62 \pm 0.26 \mathrm{~b}$ & $0.53 \pm 0.14 \mathrm{a}$ & $0.29 \pm 0.13 \mathrm{a}$ & $0.67 \pm 0.22 b c$ & $1.31 \pm 0.16 \mathrm{c}$ \\
\hline \multirow{5}{*}{$\mathrm{Cu}$} & $\mathrm{CK}$ & $23.69 \pm 1.22 \mathrm{c}$ & $6.77 \pm 0.35 c$ & $6.42 \pm 0.87 \mathrm{bc}$ & $6.91 \pm 0.43 \mathrm{a}$ & $0.98 \pm 0.02 \mathrm{a}$ & $0.29 \pm 0.02 \mathrm{c}$ \\
\hline & NELM & $44.93 \pm 10.11 \mathrm{~b}$ & $5.47 \pm 0.61 \mathrm{~d}$ & $5.33 \pm 1.93 \mathrm{c}$ & $5.73 \pm 0.46 \mathrm{bc}$ & $1.01 \pm 0.13 \mathrm{a}$ & $0.12 \pm 0.06 \mathrm{c}$ \\
\hline & NEHM & $57.52 \pm 9.86 \mathrm{a}$ & $7.00 \pm 0.46 \mathrm{c}$ & $5.47 \pm 0.59 \mathrm{c}$ & $5.00 \pm 0.61 \mathrm{~d}$ & $0.75 \pm 0.11 \mathrm{~b}$ & $0.12 \pm 0.05 \mathrm{c}$ \\
\hline & WELM & $44.93 \pm 10.11 \mathrm{~b}$ & $16.13 \pm 1.61 \mathrm{a}$ & $7.20 \pm 1.39 b$ & $6.13 \pm 1.01 \mathrm{~b}$ & $0.41 \pm 0.08 \mathrm{c}$ & $0.36 \pm 0.11 \mathrm{a}$ \\
\hline & WEHM & $57.52 \pm 9.86 \mathrm{a}$ & $11.08 \pm 2.01 \mathrm{~b}$ & $14.52 \pm 4.13 \mathrm{a}$ & $5.47 \pm 3.03 \mathrm{c}$ & $0.90 \pm 0.11 \mathrm{a}$ & $0.19 \pm 0.05 b$ \\
\hline \multirow{5}{*}{$\mathrm{Mn}$} & $\mathrm{CK}$ & $686.10 \pm 14.98 \mathrm{c}$ & $346.47 \pm 5.88 \mathrm{c}$ & $549.55 \pm 13.51 \mathrm{a}$ & $1324.72 \pm 36.11 \mathrm{a}$ & $2.70 \pm 0.78 \mathrm{a}$ & $0.50 \pm 0.05 \mathrm{c}$ \\
\hline & NELM & $1222.93 \pm 111.42 b$ & $521.33 \pm 10.20 \mathrm{~b}$ & $421.20 \pm 11.15 \mathrm{a}$ & $1015.33 \pm 21.63 b$ & $1.38 \pm 0.15 b$ & $0.43 \pm 0.15 \mathrm{c}$ \\
\hline & NEHM & $2010.83 \pm 65.45 \mathrm{a}$ & $426.97 \pm 28.96 b$ & $524.57 \pm 13.12 \mathrm{a}$ & $1072.73 \pm 16.40 \mathrm{~b}$ & $1.87 \pm 1.10 \mathrm{~b}$ & $0.21 \pm 0.09 \mathrm{~b}$ \\
\hline & WELM & $1222.93 \pm 111.42 b$ & $1336.67 \pm 8.25 \mathrm{a}$ & $507.87 \pm 27.13 \mathrm{a}$ & $1366.40 \pm 44.20 \mathrm{a}$ & $0.70 \pm 0.55 \mathrm{c}$ & $1.09 \pm 0.08 \mathrm{~b}$ \\
\hline & WEHM & $2010.83 \pm 65.45 \mathrm{a}$ & $1529.00 \pm 26.51 \mathrm{a}$ & $538.58 \pm 24.51 \mathrm{a}$ & $1083.33 \pm 38.40 \mathrm{~b}$ & $0.53 \pm 0.09 \mathrm{c}$ & $0.76 \pm 0.17 \mathrm{a}$ \\
\hline
\end{tabular}

The capital letters CK refer to no heavy metal polluted soil without ECM fungi, WELM refers to low heavy metals contaminated soil inoculated with ECM fungi, WEHM refers to high heavy metals contaminated soil inoculated with ECM fungi, NELM refers to low heavy metals contaminated soil inoculated without ECM fungi, NEHM refers to high heavy metals contaminated soil inoculated without ECM fungi; means followed with same letters within column are not significantly different by Tukey's test multiple comparison at $\mathrm{p}<0.05$, mean \pm standard error of three measurements

\section{Effect of ECM fungi on physicochemical properties of soil}

The physicochemical properties of soil were changed significantly between WE and NE treatments (Fig. 3). The water content of soil was increased by $84 \%$ in WELM and $45 \%$ in WEHM treatment than that in NE treatment, respectively. The available $\mathrm{N}$ content was increased by $64 \%$ in WELM and $13.3 \%$ in WEHM than that in NE treatment, respectively. The $\mathrm{C} / \mathrm{N}$ ratio of the soil in $\mathrm{WE}$ treatment changed greatly, especially in WELM soil, and the soil $\mathrm{C} / \mathrm{N}$ is about $22 \%$ higher than that in NE treatment. The contents of $\mathrm{P}$ and $\mathrm{K}$ in WELM plot was significant increased compared to $\mathrm{CK}$. The highest $\mathrm{N}$ content was found in WE treatment of the soil $(\mathrm{p}<0.05)$. The overall results showed that the inoculation of ECM fungi could significantly improve the soil structure and physicochemical properties. 

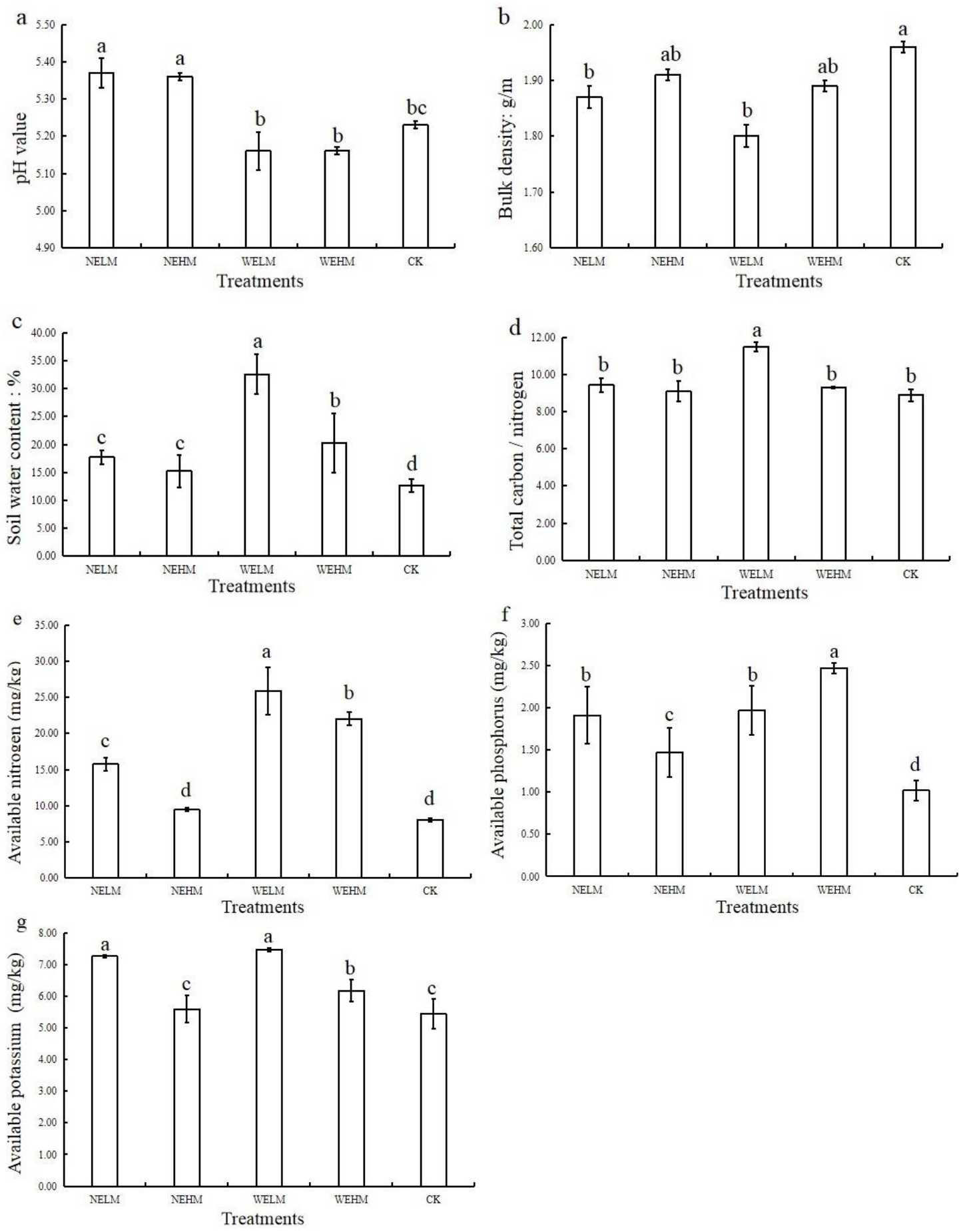

Figure 3. The soil physicochemical properties of soil under different treatments. (Note: a refers the soil $p H$ value, $b$ refers the soil bulk density, $c$ refers the soil water content, $d$ refers the ratio of total carbon to total nitrogen, e refers the soil available nitrogen, f refers the soil available phosphorus, g refers the soil available potassium; the capital letter CK refers to no heavy metal polluted soil without ECM fungi, WELM refers to low heavy metals contaminated soil inoculated with ECM fungi, WEHM refers to high heavy metals contaminated soil inoculated with ECM fungi, NELM refers to low heavy metals contaminated soil inoculated without ECM fungi, NEHM refers to high heavy metals contaminated soil inoculated without ECM fungi; means followed with same letters are not significantly different by Tukey's test multiple comparison at $p<0.05$, mean \pm standard error of three measurements) 
Table 3. Accumulation and transport of nutrient elements in masson's pine under different treatments

\begin{tabular}{|c|c|c|c|c|c|c|}
\hline Element & Treatment & $\begin{array}{l}\text { Average plant } \\
\text { content }\end{array}$ & Root $(\mathrm{mg} / \mathrm{kg})$ & Stem $(\mathbf{m g} / \mathbf{k g})$ & Leave (mg/kg) & $\begin{array}{c}\text { Above- } \\
\text { /underground }\end{array}$ \\
\hline \multirow{5}{*}{$\mathrm{Se}$} & $\mathrm{CK}$ & $2.82 \pm 0.14 \mathrm{ab}$ & $3.12 \pm 0.41 \mathrm{a}$ & $2.74 \pm 0.62 b$ & $2.61 \pm 0.32 \mathrm{bc}$ & $0.86 \pm 0.29 \mathrm{c}$ \\
\hline & NELM & $2.27 \pm 0.42 \mathrm{~b}$ & $1.33 \pm 0.83 \mathrm{c}$ & $2.00 \pm 0.40 \mathrm{c}$ & $3.47 \pm 0.61 \mathrm{a}$ & $2.01 \pm 1.53 \mathrm{a}$ \\
\hline & NEHM & $2.61 \pm 0.33 b$ & $3.00 \pm 0.52 \mathrm{a}$ & $3.77 \pm 0.35 \mathrm{a}$ & $1.07 \pm 0.42 \mathrm{~d}$ & $0.81 \pm 0.31 \mathrm{bc}$ \\
\hline & WELM & $3.02 \pm 0.58 \mathrm{a}$ & $3.33 \pm 0.83 \mathrm{a}$ & $2.93 \pm 0.83 b$ & $2.80 \pm 1.06 \mathrm{~b}$ & $0.86 \pm 0.42 \mathrm{c}$ \\
\hline & WEHM & $2.73 \pm 0.67 \mathrm{ab}$ & $1.75 \pm 0.76 \mathrm{~b}$ & $2.18 \pm 0.95 \mathrm{c}$ & $2.27 \pm 1.22 \mathrm{c}$ & $1.27 \pm 0.22 \mathrm{~b}$ \\
\hline \multirow{5}{*}{$\mathrm{Fe}$} & $\mathrm{CK}$ & $1121.57 \pm 54.53 \mathrm{~b}$ & $2887 \pm 112.67 \mathrm{~cd}$ & $166.43 \pm 15.91 \mathrm{~cd}$ & $311.27 \pm 53.61 \mathrm{~b}$ & $0.08 \pm 0.01 \mathrm{a}$ \\
\hline & NELM & $1263.34 \pm 21.64 b$ & $3241.07 \pm 78.54 \mathrm{~cd}$ & $187.47 \pm 5.90 \mathrm{c}$ & $361.47 \pm 124.45 \mathrm{a}$ & $0.08 \pm 0.05 \mathrm{a}$ \\
\hline & NEHM & $3172.16 \pm 64.36 \mathrm{a}$ & $8916.83 \pm 179.21 \mathrm{~b}$ & $216.77 \pm 20.23 b$ & $382.87 \pm 56.08 \mathrm{a}$ & $0.07 \pm 0.01 \mathrm{~b}$ \\
\hline & WELM & $1334.04 \pm 15.67 \mathrm{~b}$ & $3528.80 \pm 81.86 \mathrm{c}$ & $229.20 \pm 21.70 b$ & $244.13 \pm 14.52 \mathrm{c}$ & $0.07 \pm 0.03 \mathrm{~b}$ \\
\hline & WEHM & $3415.45 \pm 43.40 \mathrm{a}$ & $9694.10 \pm 629.86 \mathrm{a}$ & $405.73 \pm 59.97 \mathrm{a}$ & $146.53 \pm 21.87 \mathrm{~d}$ & $0.03 \pm 0.01 \mathrm{c}$ \\
\hline \multirow{5}{*}{$P$} & CK & $955.89 \pm 21.33 \mathrm{~b}$ & $786.82 \pm 22.06 \mathrm{~b}$ & $924.71 \pm 83.19 \mathrm{c}$ & $1156.13 \pm 24.63 b$ & $1.32 \pm 0.22 b$ \\
\hline & NELM & $834.31 \pm 4.33 b$ & $1493.60 \pm 50.61 \mathrm{a}$ & $881.47 \pm 37.13 \mathrm{~cd}$ & $1127.87 \pm 48.50 \mathrm{~b}$ & $2.04 \pm 1.63 \mathrm{a}$ \\
\hline & NEHM & $922.58 \pm 8.67 \mathrm{~b}$ & $759.33 \pm 4.55 b$ & $892.27 \pm 20.87 \mathrm{~cd}$ & $1116.13 \pm 30.44 b$ & $1.32 \pm 0.51 \mathrm{~b}$ \\
\hline & WELM & $1149.41 \pm 21.57 \mathrm{a}$ & $788.97 \pm 38.89 b$ & $1282.00 \pm 97.96 \mathrm{~b}$ & $1377.27 \pm 50.04 \mathrm{a}$ & $1.69 \pm 1.81 \mathrm{ab}$ \\
\hline & WEHM & $1358.98 \pm 27.33 \mathrm{a}$ & $1362.48 \pm 44.27 \mathrm{a}$ & $1321.52 \pm 49.71 \mathrm{a}$ & $1392.93 \pm 41.46 \mathrm{a}$ & $1.00 \pm 0.41 \mathrm{c}$ \\
\hline \multirow{5}{*}{ K } & CK & $5902.64 \pm 126.30 \mathrm{~b}$ & $7382.41 \pm 134.3 b$ & $5006.57 \pm 102.31 \mathrm{~b}$ & $5318.95 \pm 85.33 c$ & $0.70 \pm 0.51 \mathrm{bc}$ \\
\hline & NELM & $4834.62 \pm 59.77 \mathrm{~b}$ & $6082.67 \pm 50.6 \mathrm{c}$ & $4125.20 \pm 130.83 \mathrm{bc}$ & $4296.00 \pm 154.35 \mathrm{~cd}$ & $0.69 \pm 0.12 \mathrm{bc}$ \\
\hline & NEHM & $7584.53 \pm 121.57 \mathrm{a}$ & $8269.53 \pm 296.19 \mathrm{a}$ & $7572.10 \pm 462.22 \mathrm{a}$ & $6911.97 \pm 326.31 \mathrm{a}$ & $0.88 \pm 0.25 b$ \\
\hline & WELM & $2980.53 \pm 67.53 \mathrm{c}$ & $2387.73 \pm 86.43 \mathrm{~d}$ & $2932.27 \pm 90.55 \mathrm{~d}$ & $3621.60 \pm 138.28 \mathrm{~d}$ & $1.37 \pm 0.38 \mathrm{a}$ \\
\hline & WEHM & $6022.83 \pm 156.71 \mathrm{a}$ & $7530.65 \pm 860.35 \mathrm{ab}$ & $4361.85 \pm 329.59 \mathrm{bc}$ & $6176.00 \pm 207.88 \mathrm{~b}$ & $0.70 \pm 0.11 \mathrm{bc}$ \\
\hline \multirow{5}{*}{$\mathrm{N}$} & $\mathrm{CK}$ & $3034.64 \pm 63.43 \mathrm{a}$ & $1793.5 \pm 35.1 \mathrm{~b}$ & $2505.67 \pm 112.30 \mathrm{~b}$ & $4804.76 \pm 76.19 \mathrm{c}$ & $2.04 \pm 0.81 \mathrm{ab}$ \\
\hline & NELM & $2542.74 \pm 27.36 b$ & $1537.23 \pm 114.52 \mathrm{c}$ & $2536.52 \pm 103.32 b$ & $3554.46 \pm 200.87 \mathrm{~d}$ & $1.98 \pm 0.98 \mathrm{~b}$ \\
\hline & NEHM & $2690.92 \pm 151.31 b$ & $1855.63 \pm 89.51 \mathrm{~b}$ & $2125.36 \pm 115.69 \mathrm{bc}$ & $3256.47 \pm 187.58 \mathrm{~d}$ & $1.45 \pm 0.11 \mathrm{c}$ \\
\hline & WELM & $3910.35 \pm 51.31 \mathrm{a}$ & $2050.53 \pm 91.88 \mathrm{a}$ & $3144.29 \pm 196.38 \mathrm{a}$ & $6536.23 \pm 285.48 \mathrm{a}$ & $2.36 \pm 0.53 \mathrm{a}$ \\
\hline & WEHM & $3451.41 \pm 136.67 \mathrm{a}$ & $1998.86 \pm 105.32 \mathrm{ab}$ & $2856.35 \pm 123.56 \mathrm{ab}$ & $5499.01 \pm 324.25 \mathrm{~b}$ & $2.09 \pm 1.01 \mathrm{ab}$ \\
\hline
\end{tabular}

The capital letters CK refer to no heavy metal polluted soil without ECM fungi, WELM refers to low heavy metals contaminated soil inoculated with ECM fungi, WEHM refers to high heavy metals contaminated soil inoculated with ECM fungi, NELM refers to low heavy metals contaminated soil inoculated without ECM fungi, NEHM refers to high heavy metals contaminated soil inoculated without ECM fungi; means followed with same letters within column are not significantly different by Tukey's test multiple comparison at $\mathrm{p}<0.05$, mean \pm standard error of three measurements

\section{Effect of ECM fungi on soil enzymes}

Soil enzyme plays an important role in recycling of nutrients, which is closely related to soil microorganisms and plant community structure. It is a sensitive index to evaluate soil fertility and soil quality. The results showed that the enzyme activity in WE treatment was significantly different from that of control treatment $(\mathrm{CK})$ and $\mathrm{NE}$ treatment $(\mathrm{p}<0.05)$ (Table 4). The urease and alkaline phosphatase contents in WE treatment was significantly higher than that of NE treatment $(\mathrm{P}<0.05)$, while there was no significant different in catalase and sucrase content among different treatments.

\section{The correlation between the soil physicochemical properties and plant nutrients}

The correlations between the soil physicochemical properties of soil and the contents of macro nutrients in masson's pine seedlings were analyzed (Table 5). The results showed that there were correlations between soil physicochemical properties and the 
accumulation of macro nutrient. The soil $\mathrm{pH}$ correlated negatively with all the nutrient elements of plant, excepting the K. Especially, the significantly negative correlation was found between the concentration of $\mathrm{N}$ and soil $\mathrm{pH}$ (Table 5). The soil water content was positively correlated with plant $\mathrm{Se}, \mathrm{N}, \mathrm{P}$ elements, while the negatively correlation was found between soil water content and the plant Fe and $\mathrm{K}$ (Table 5). There was positive correlation of $\mathrm{N}$ and $\mathrm{P}$ between the plants and the LM and HM soils, while the content of $\mathrm{K}$ in plant was negatively correlated with the available $\mathrm{K}$ content in the soil. The results of correlation analysis of soil enzymes and soil physicochemical properties showed that urease had a significantly negative relationship with soil $\mathrm{pH}$, while there was no significant relationship between the soil urease and bulk density (Table 5). Both Urease and alkaline phosphatase positively correlated with soil nutrient elements. Sucrase negatively correlated with the soil properties (excepting the soil $\mathrm{pH}$ and the soil bulk density), especially with the available nitrogen $(\mathrm{N})$ and phosphorus $(\mathrm{P})$ contents of the soil. Altogether, plants inoculated with ECM fungi could increase the activities of catalase, urease and alkaline phosphates and therefore improved the soil physicochemical properties.

Table 4. Enzyme activity indexes of soil main enzymes under different treatments

\begin{tabular}{c|c|c|c|c}
\hline Treatment & Catalase $(\mathbf{m g} / \mathbf{g})$ & Urease $(\mathbf{m g} / \mathbf{g})$ & Alkaline phosphatase $(\mathbf{m g} / \mathbf{g})$ & Sucrase (mg/g) \\
\hline CK & $3.13 \pm 0.04 \mathrm{a}$ & $0.39 \pm 0.05 \mathrm{~b}$ & $52.96 \pm 3.52 \mathrm{ab}$ & $0.40 \pm 0.10 \mathrm{a}$ \\
NELM & $2.96 \pm 0.09 \mathrm{ab}$ & $0.27 \pm 0.03 \mathrm{~b}$ & $41.86 \pm 1.71 \mathrm{~b}$ & $0.26 \pm 0.04 \mathrm{a}$ \\
WELM & $3.13 \pm 0.09 \mathrm{a}$ & $0.58 \pm 0.06 \mathrm{a}$ & $69.66 \pm 9.44 \mathrm{a}$ & $0.35 \pm 0.08 \mathrm{a}$ \\
NEHM & $2.77 \pm 0.13 \mathrm{~b}$ & $0.17 \pm 0.05 \mathrm{c}$ & $40.13 \pm 4.09 \mathrm{~b}$ & $0.22 \pm 0.04 \mathrm{a}$ \\
WEHM & $3.02 \pm 0.08 \mathrm{ab}$ & $0.46 \pm 0.05 \mathrm{ab}$ & $51.72 \pm 5.1 \mathrm{ab}$ & $0.23 \pm 0.04 \mathrm{a}$ \\
\hline
\end{tabular}

The capital letters CK refer to no heavy metal polluted soil without ECM fungi; WELM refers to low heavy metals contaminated soil inoculated with ECM fungi, WEHM refers to high heavy metals contaminated soil inoculated with ECM fungi, NELM refers to low heavy metals contaminated soil inoculated without ECM fungi, NEHM refers to high heavy metals contaminated soil inoculated without ECM fungi; means followed with same letters within column are not significantly different by Tukey's test multiple comparison at $\mathrm{p}<0.05$, mean \pm standard error of three measurements

Table 5. The correlations between the soil physicochemical properties and the soil nutrient elements contents in masson's pine seedings

\begin{tabular}{c|c|c|c|c|c|c}
\hline & $\begin{array}{c}\text { Soil } \\
\text { pH }\end{array}$ & $\begin{array}{c}\text { Bulk } \\
\text { density }\end{array}$ & $\begin{array}{c}\text { Moisture } \\
\text { content }\end{array}$ & $\begin{array}{c}\text { Available } \\
\text { nitrogen }\end{array}$ & $\begin{array}{c}\text { Available } \\
\text { phosphorus }\end{array}$ & $\begin{array}{c}\text { Available } \\
\text { potassium }\end{array}$ \\
\hline $\mathrm{Se}$ & -0.370 & -0.201 & 0.412 & 0.041 & -0.495 & 0.013 \\
$\mathrm{Fe}$ & -0.024 & 0.143 & -0.152 & 0.040 & 0.428 & -0.414 \\
$\mathrm{~N}$ & $-0.929 *$ & -0.563 & 0.807 & 0.773 & 0.408 & 0.331 \\
$\mathrm{P}$ & -0.856 & -0.282 & 0.479 & 0.690 & 0.683 & 0.054 \\
$\mathrm{~K}$ & 0.457 & 0.776 & -0.817 & -0.728 & -0.311 & -0.854 \\
Catalase & -0.750 & -0.182 & 0.406 & 0.409 & -0.013 & 0.285 \\
Urease & $-0.927 *$ & -0.518 & 0.747 & 0.764 & 0.335 & 0.431 \\
Alkaline phosphatase & -0.838 & -0.570 & 0.804 & 0.676 & 0.119 & 0.424 \\
Sucrase & 0.379 & 0.854 & -0.785 & $-0.944 *$ & $-0.912 *$ & -0.813 \\
\hline
\end{tabular}

*Significantly different by Tukey's test multiple comparison at $\mathrm{p}<0.05$, mean \pm standard error of three measurements 


\section{Discussion}

\section{Tolerance and adaptability of ECM fungi on masson's pine seedlings in mining area}

Soil bioremediation based on plant-microorganism symbiotic system has become a hot topic of researches (Kurzawova et al., 2012; Becerra-Castro et al., 2012). Many studies have shown that herbaceous plants have a strong ability to absorb and accumulate heavy metals (Leguizamo et al., 2017; Xue et al., 2014). In recent years, researchers have also tried to use woody plants with larger amount of biomass for forest restoration (Shi et al., 2011). For example, Shukla et al. (2011) chose five species of woody plant for the phytoremediation of heavy metals of sludge dumps in India, and the results showed that all the five plants had high bioconcentration factor for different metals and the remove rate of heavy metals were from 14.05 to $70.22 \%$ (Shukla et al., 2011). It is worth noting that many plant species largely rely on mycorrhizal fungi, which enhance nutrient uptake and protect against environmental stresses (Krznaric et al., 2009a), especially in the heavy metal contaminated stress (Adriaensen et al., 2006; Krznaric et al., 2009b).

In our research, the growth parameters, height, lateral branches and the ground diameter of the masson's pine inoculated with ECM fungi were significantly higher than those of the control and the masson's pine inoculated without ECM fungi during the experimental study in the mining area (Fig. 1). Moreover, masson's pine inoculated with ECM fungi could enhance the accumulation of heavy metals (Table 2), and the absorbed metals such as $\mathrm{Pb}, \mathrm{Zn}, \mathrm{Cd}, \mathrm{Cu}, \mathrm{Mn}$ elements were immobilized in roots system, which reduced the transportation of heavy metals to the aboveground part and alleviated the toxicity of heavy metals to the plant (Table 3). Our result was consistent with Reddy et al. (2016) that growth performance of plants was improved significantly inoculated with ectomycorrhizal fungi (Pisolithus albus) in the stress of $\mathrm{Cu}$ and $\mathrm{Cd}$, which proved that ectomycorrhizal fungi could help plants to adapt to the heavy metal stress environment (Reddy et al., 2016). Similar results were also reported by other ectomycorrhizal fungi studies where heavy metals transfer to the host plants was significantly reduced (Krznaric et al., 2009b; Colpaert et al., 2005). Mycorrhizal fungi contribute not only to the uptake and detoxification of various environmental pollutants including heavy metals, but also to plant nutrition (Perotto and Martino, 2001). The result was consistent with our results that ECM fungi inoculation could promote the plant absorption and accumulation of essential elements $\mathrm{Fe}, \mathrm{N}, \mathrm{P}, \mathrm{K}$, and $\mathrm{Se}$ in the aboveground and underground parts of masson's pine under heavy metals stress in soil. The Se element could enhance the activity of plant antioxidant enzymes and the resistance of heavy metals stress.

\section{Effects of ECM fungi on nutrient elements and soil enzyme in heavy metals contaminated soils}

Soil enzyme is the most important catalyst of all biochemical reactions in soil biological activity (Nannipieri et al., 2018), and it is the most active bioactive substance in the degradation, transformation, and mineralization of soil organic matter (SOM) thereby maintaining energy flow and change the composition and structure of nutrient elements in soil, which was of great significance to plant growth (Sinsabaugh, 2010), and further alleviate the stress of the environment to the plants (Angelovičová et al., 2015).

In our study, the ECM fungi could activate the soil urease and the phosphatase, and increased the available nitrogen and the phosphorus contents in the soil for the plants to 
uptake it. Furthermore, the enzyme activities had significant negative correlation with soil $\mathrm{pH}$, and positively correlated with available $\mathrm{N}, \mathrm{P}$, and $\mathrm{K}$ contents in soil, while the soil $\mathrm{pH}$ had significantly negative correlation with the $\mathrm{N}, \mathrm{P}$ contents in plants, so that there was a significantly positive correlation between N, P contents in masson's pine plants and urease and alkaline phosphates in soil. ECM fungi could form mutual symbiotic system with majorities of plants' roots (Burke et al., 2011), and play a vital role in enzyme activities which correlated with nutrient absorption such as nitrogen and/or phosphorus (Eichlerová et al., 2015). Previously studies shown that ECM fungi could expand the absorption area of plant roots through hyphae, and then increase the nutrient uptake in plant rhizosphere, especially in soil available P (Cairney, 2011; Köhler et al., 2018). According to Taniguchi et al. (2008), the inoculation of ECM fungi significantly increased the growth of plants, which significantly related to the content of phosphorus, the ratio of nitrogen to phosphorus and plant rhizosphere soil phosphatase (Taniguchi et al., 2008).

\section{Conclusions}

In this study, we investigated the effects of masson's pine inoculated with ECM fungi (Suillus luteus) on soil physicochemical properties by evaluating the soil bulk density, water content, soil available nutrients and soil $\mathrm{pH}$. The heavy metals accumulation and translocation in multi-metals of mining areas was also analyzed. The results showed that the masson's pine inoculated with ECM fungi growing in the heavy metals contaminated soils increased the growth of masson's pine in ground base diameter, annual branch length and crown width. Soil enzymatic activities were significantly improved in the mutualistic symbiosis systems of Suillus-Pine, especially the activities of urease and alkaline phosphatase, indicating the potential to obtain more nutrient elements. An immobilization of $\mathrm{Pb}, \mathrm{Zn}, \mathrm{Cd}, \mathrm{Cu}, \mathrm{Mn}$ was observed in the roots of plant inoculated with Suillus luteus, and correspondingly decreased the translocation of heavy metals in the plants' roots may due to the detoxification. Two enzymes decreased the soil $\mathrm{pH}$ and increased the soil available of $\mathrm{N}, \mathrm{P}, \mathrm{K}$ contents, enhancing the growth of masson's pine. Our results provided the information to understand the adaptation and bioremediation of plants mycorrhizal to detoxify the heavy metals from the environment, and provided a theoretical basis in allocation and transformation of heavy metals in the case of multi-metals contaminated soil in mining area.

Considered that, future research should pay more attention to the difference of rhizosphere microbial community diversity in different contaminated sites and its influence on the restoration effect of heavy metals.

Acknowledgements. This work supported by The Key R\&D Project of Science and Technology Granted by Hunan Government (2019Sk2191), Scientific Innovation Fund for Post-graduates of Central South University of Forestry and Technology (20183038) and Changsha Municipal Government (kq1801080). And we helpful comments by the following graduate students for their assistance in laboratory chemical analysis: Xiao Zhou, Xuechun Feng and Qinyi Wang.

\section{REFERENCES}

[1] Adriaensen, K., Vangronsveld, J., Colpaert, J. V. (2006): Zinc tolerant Suillus bovinus improves growth of Zn-exposed Pinus sylvestris seedlings. - Mycorrhiza 16: 553-558. 
[2] Angelovičová, L., Bobul'ská, L., Fazekašová, D. (2015): Toxicity of heavy metals to soil biological and chemical properties in conditions of environmentally polluted area middle Spiš (Slovakia). - Carpathian Journal of Earth and Environmental Sciences 10(1): 193201.

[3] Ayangbenro, A., Babalola, O. (2017): A new strategy for heavy metal polluted environments: a review of microbial biosorbents. - International Journal of Environmental Research and Public Health 14(1): 94.

[4] Bao, S. (2000): The Soil Agricultural Chemistry Analysis. - Chinese Agriculture Press, Beijing (in Chinese).

[5] Becerra-Castro, C., Monterroso, C., Prieto-Fernández, A., Rodríguez-Lamas, L., Loureiro-Viñas, M., Acea, M. J., Kidd, P. S. (2012): Pseudometallophytes colonising $\mathrm{Pb} / \mathrm{Zn}$ mine tailings: a description of the plant-microorganism-rhizosphere soil system and isolation of metal-tolerant bacteria. - Journal of Hazardous materials 217: 350-359.

[6] Burke, D. J., Weintraub, M. N., Hewins, C. R., Kalisz, S. (2011): Relationship between soil enzyme activities, nutrient cycling and soil fungal communities in a northern hardwood forest. - Soil Biology and Biochemistry 43(4): 795-803.

[7] Cairney, J. W. (2011): Ectomycorrhizal fungi: the symbiotic route to the root for phosphorus in forest soils. - Plant and Soil 344(1-2): 51-71.

[8] Colpaert, J. V. (2008): Heavy Metal Pollution and Genetic Adaptations in Ectomycorrhizal Fungi. - In: Avery, S. V., Stratford, M., Van West, P. (eds.) Stress in Yeasts and Filamentous Fungi. British Mycological Society Symposia Series, Vol. 27. Academic, Amsterdam, pp. 157-174.

[9] Colpaert, J. V., Adriaensen, K., Muller, L. A. H., Lambaerts, M., Faes, C., Carleer, R., Vangronsveld, J. (2005): Element profiles and growth in Zn-sensitive and Zn-resistant Suilloid fungi. - Mycorrhiza 15: 628-634

[10] Eichlerová, I., Homolka, L., Žifčáková, L., Lisá, L., Dobiášová, P., Baldrian, P. (2015): Enzymatic systems involved in decomposition reflects the ecology and taxonomy of saprotrophic fungi. - Fungal Ecol. 13: 10-22.

[11] Guan, S., Zhang, D., Zhang, Z. (1986): Soil Enzyme and Its Research Methods. Agricultural, Beijing (in Chinese).

[12] Guo, J., Lv, X., Jia, H., Hua, L., Ren, X., Muhammad, H., Ding, Y. (2020): Effects of EDTA and plant growth-promoting rhizobacteria on plant growth and heavy metal uptake of hyperaccumulator Sedum alfredii Hance. - Journal of Environmental Sciences 88: 361-369.

[13] Huai, W., Guo, L., He, W. (2003): Genetic diversity of an ectomycorrhizal fungus Tricholoma terreum in a Larix principis-rupprechtii stand assessed using random amplified polymorphic DNA. - Mycorrhiza 13(5): 265-270.

[14] Huang, J., Nara, K., Lian, C., Zong, K., Peng, K., Xue, S., Shen, Z. (2012): Ectomycorrhizal fungal communities associated with Masson pine (Pinus massoniana Lamb.) in Pb-Zn mine sites of central south China. - Mycorrhiza 22: 589-602.

[15] Jentschke, G., Godbold, D. L. (2000): Metal toxicity and ectomycorrhizas. - Physiol Plant 109: 107-116.

[16] Köhler, J., Yang, N., Pena, R., Raghavan, V., Polle, A., Meier, I. C. (2018): Ectomycorrhizal fungal diversity increases phosphorus uptake efficiency of European beech. - New Phytologist 220(4): 1200-1210.

[17] Krznaric, E., Verbruggen, N., Wevers, J. H. L., Carleer, R., Vangronsveld, J., Colpaert, J. V. (2009a): Cd-tolerant Suillus luteus: a fungal insurance for pines exposed to Cd. Environ Pollut 157: 1581-1588.

[18] Krznaric, E., Wevers, J. H. L., Cloquet, C., Vangronsveld, J., Vanhaecke, F., Colpaert, J. V. (2009b): Zn pollution counteracts Cd toxicity in metal-tolerant ectomycorrhizal fungi and their host plant, Pinus sylvestris. - Environ Microbiol 12: 2133-2141. 
[19] Kurzawova, V., Stursa, P., Uhlik, O., Norkova, K., Strohalm, M., Lipov, J., Mackova, M. (2012): Plant-microorganism interactions in bioremediation of polychlorinated biphenylcontaminated soil. - New Biotechnology 30(1): 15-22.

[20] Lalancette, S., Lerat, S., Roy, S., Beaulieu, C. (2019): Fungal endophytes of Alnus incana ssp. rugosa and Alnus alnobetula ssp. crispa and their potential to tolerate heavy metals and to promote plant growth. - Mycobiology 1-15.

[21] Leguizamo, M. A. O., Gómez, W. D. F., Sarmiento, M. C. G. (2017): Native herbaceous plant species with potential use in phytoremediation of heavy metals, spotlight on wetlands-a review. - Chemosphere 168: 1230-1247.

[22] Li, K., Yang, B., Wang, H., Xu, X., Gao, Y., Zhu, Y. (2019): Dual effects of biochar and hyperaccumulator Solanum nigrum L. on the remediation of Cd-contaminated soil. - Peer J. 7: e6631.

[23] Luo, Z., Wu, C., Zhang, C., Li, H., Lipka, U., Polle, A. (2014): The role of ectomycorrhizas in heavy metal stress tolerance of host plants. - Environ. Exp. Bot. 108: 47-62.

[24] Ma, Y., Rajkumar, M., Oliveira, R. S., Zhang, C., Freitas, H. (2019): Potential of plant beneficial bacteria and arbuscular mycorrhizal fungi in phytoremediation of metalcontaminated saline soils. - Journal of Hazardous Materials 379: 120813.

[25] Nannipieri, P., Trasar-Cepeda, C., Dick, R. P. (2018): Soil enzyme activity: a brief history and biochemistry as a basis for appropriate interpretations and meta-analysis. Biology and Fertility of Soils 54(1): 11-19.

[26] Perotto, S., Martino, E. (2001): Molecular and cellular mechanisms of heavy metal tolerance in mycorrhizal fungi: what perspectives for bioremediation? - Minerva Biotecnol. 13: 55-63.

[27] Reddy, M. S., Kour, M., Aggarwal, S., Ahuja, S., Marmeisse, R., Fraissinet-Tachet, L. (2016): Metal induction of a P isolithus albus metallothionein and its potential involvement in heavy metal tolerance during mycorrhizal symbiosis. - Environmental Microbiology 18(8): 2446-2454.

[28] Sheoran, V., Sheoran, A., Poonia, P. (2011): Role of hyperaccumulators in phytoextraction of metals from contaminated mining sites: a review. - Crit. Rev. Environ. Sci. Technol. 41: 168-214.

[29] Shi, X., Zhang, X., Chen, G., Chen, Y., Wang, L., Shan, X. (2011): Seedling growth and metal accumulation of selected woody species in copper and lead/zinc mine tailings. Journal of Environmental Sciences 23(2): 266-274.

[30] Shukla, O. P., Juwarkar, A. A., Singh, S. K., Khan, S., Rai, U. N. (2011): Growth responses and metal accumulation capabilities of woody plants during the phytoremediation of tannery sludge. - Waste Management 31(1): 115-123.

[31] Sinsabaugh, R. L. (2010): Phenol oxidase, peroxidase and organic matter dynamics of soil. - Soil Biol Biochem 42: 391-404.

[32] Sousa, N. R., Ramos, M. A., Marques, A. P., Castro, P. M. (2012): The effect of ectomycorrhizal fungi forming symbiosis with Pinus pinaster seedlings exposed to cadmium. - Science of the Total Environment 414: 63-67.

[33] Sozoniuk, M., Nowak, M., Dudziak, K., Bulak, P., Leśniowska-Nowak, J., Kowalczyk, K. (2019): Antioxidative system response of pedunculate oak (Quercus robur L.) seedlings to Cd exposure. - Physiology and Molecular Biology of Plants 25(6): 13771384.

[34] Sun, F., Wen, D., Kuang, Y., Li, J., Zuo, W. (2010): Concentrations of heavy metals and polycyclic aromatic hydrocarbons in needles of Masson pine (Pinus massoniana L.) growing nearby different industrial sources. - J. Environ. Sci. 22: 1006-1013.

[35] Tam, P. C. (1995): Heavy metal tolerance by ectomycorrhizal fungi and metal amelioration by Pisolithus tinctorius. - Mycorrhiza 5(3): 181-187.

[36] Taniguchi, T., Kataoka, R., Futai, K. (2008): Plant growth and nutrition in pine (Pinus thunbergii) seedlings and dehydrogenase and phosphatase activity of ectomycorrhizal 
root tips inoculated with seven individual ectomycorrhizal fungal species at high and low nitrogen conditions. - Soil Biology and Biochemistry 40(5): 1235-1243.

[37] Wang, Z., Qin, H., Wang, J. (2019): Needle pigment responses of Pinus massoniana L. to soils polluted with the heavy metals $\mathrm{Zn}, \mathrm{Pb}$ and $\mathrm{Cu}$. - Geochemistry: Exploration, Environment, Analysis 19(1): 1-5.

[38] Wuana, R. A., Okieimen, F. E. (2011): Heavy metals in contaminated soils: a review of sources, chemistry, risks and best available strategies for remediation. - ISRN Ecol. 2011: 1-20.

[39] Xue, L., Liu, J., Shi, S., Wei, Y., Chang, E., Gao, M., Jiang, Z. (2014): Uptake of heavy metals by native herbaceous plants in an antimony mine (Hunan, China). - CLEAN-Soil, Air, Water 42(1): 81-87.

[40] Yin, D., Deng, X., Chet, I., Song, R. (2014): Physiological responses of Pinus sylvestris var. mongolica seedlings to the interaction between Suillus luteus and Trichoderma virens. - Current Microbiology 69(3): 334-342.

[41] Yu, P., Sun, Y., Huang, Z., Zhu, F., Sun, Y., Jiang, L. (2020): The effects of ectomycorrhizal fungi on heavy metals' transport in Pinus massoniana and bacteria community in rhizosphere soil in mine tailing area. - Journal of Hazardous Materials 381: 121203.

[42] Zhang, T., Wen, X., Ding, G. (2017): Ectomycorrhizal symbiosis enhances tolerance to low phosphorous through expression of phosphate transporter genes in masson pine (Pinus massoniana). - Acta Physiol. Plant 39: 101.

[43] Zhang, X., Li, M., Yang, H., Li, X., Cui, Z. (2018): Physiological responses of Suaeda glauca and Arabidopsis thaliana in phytoremediation of heavy metals. - Journal of Environmental Management 223: 132-139.

[44] Zhang, Y., Ji, H. (2019): Physiological responses and accumulation characteristics of turfgrasses exposed to potentially toxic elements. - Journal of Environmental Management 246: 796-807.

[45] Zhao, X., Liu, J., Xia, X., Chu, J., Wei, Y., Shi, S., Chang, E., Yin, W., Jiang, Z. (2013): The evaluation of heavy metal accumulation and application of a comprehensive bioconcentration index for woody species on contaminated sites in Hunan, China. - Environ. Sci. Pollut. Res. 21: 5076-5085. 